\title{
PENINGKATAN KETERAMPILAN GURU DALAM MENGGUNAKAN MEDIA PEMBELAJARAN MELALUI METODE KERJA KELOMPOK DI SDN 011 TANJUNG PENYEMBAL KOTA DUMAI TAHUN PELAJARAN 2018/2019
}

\author{
Firman Edi \\ Dinas Pendidikan dan Kebudayaan Kota Dumai \\ Email: firmanedips@gmail.com
}

\begin{abstract}
Based on the results of observations that have been made, it is known that the percentage of teachers at SDN 011 Tanjung Pembal Dumai City who have skills in using learning media is very small, which is only $24.4 \%$. This means that $75.6 \%$ of teachers at SDN 011 Tanjung Pembal Dumai City lack the skills to use learning media properly. One of the efforts made by supervisors at SDN 011 Tanjung Penyembal Dumai City in improving the skills of teachers in using learning media is to do group work activities. In accordance with the formulation of the problem and the hypothesis of the action, the purpose of this study is "to determine the improvement of teacher skills in using learning media through working groups at SDN 011 Tanjung Penyembal, Dumai City. This research uses the Kurt Lewin School Action Research design. The main concept of PTS according to Kurt Lewin consists of four components, namely: planning (planning), action (acting), observation (observating), and reflection (reflecting). The relationship between the four components is seen as a cycle. The conclusion of this study is based on research findings that in the pre-cycle the average skill of teachers in using learning media is only $24.4 \%$. After the group work was carried out in the first cycle, the teacher's skills in using learning media increased by 58.6\%. After making improvements in carrying out group work in cycle II, the teacher's skills in using learning media increased by $84.8 \%$. Thus the action hypothesis in this study was accepted, namely "There is an increase in teacher skills in using learning media through group work at SDN 011 Tanjung Penyembal Dumai City.
\end{abstract}

Keywords: Teacher Skills; Media; Work in Group 


\begin{abstract}
ABSTRAK
Berdasarkan hasil observasi yang telah dilakukan, diketahui persentase guru di SDN 011 Tanjung Penyembal Kota Dumai yang memiliki keterampilan dalam menggunakan media pembelajaran kecil sekali yaitu hanya $24,4 \%$. Artinya sebanyal $75,6 \%$ guru di SDN 011 Tanjung Penyembal Kota Dumai kurang memiliki keterampilan dalam menggunakan media pembelajaran dengan baik. Salah satu upaya yang dilakukan pengawas di SDN 011 Tanjung Penyembal Kota Dumai dalam meningkatkan keterampilan guru dalam menggunakan media pembelajaran adalah dengan melakukan kegiatan kerja kelompok. Sesuai dengan rumusan masalah dan hipotesis tindakan tersebut maka tujuan dalam penelitian ini adalah "untuk mengetahui peningkatan keterampilan guru dalam menggunakan media pembelajaran melalui kerja kelompok di SDN 011 Tanjung Penyembal Kota Dumai. Penelitian menggunakan desain Penelitian Tindakan Sekolah model Kurt Lewin. Konsep pokok PTS menurut Kurt Lewin terdiri dari empat komponen, yaitu: perencanaan (planning), tindakan (acting), pengamatan (observating), dan refleksi (reflecting). Hubungan keempat komponen itu dipandang sebagai satu siklus. Kesimpulan penelitian tersebut berdasarkan temuan penelitian bahwa pada pra siklus rata-rata keterampilan guru dalam menggunakan media pembelajaran hanya $24,4 \%$. Setelah dilaksanakan kerja kelompok pada siklus I, keterampilan guru dalam menggunakan media pembelajaran meningkat sebanyak $58,6 \%$. Setelah dilakukan perbaikan tindakan dalam melaksanakan kerja kelompok pada siklus II, keterampilan guru dalam menggunakan media pembelajaran semakin meningkat sebanyak $84,8 \%$. Dengan demikian hipotesis tindakan dalam penelitian ini diterima yaitu "Ada peningkatan keterampilan guru dalam menggunakan media pembelajaran melalui kerja kelompok di SDN 011 Tanjung Penyembal Kota Dumai.
\end{abstract}

Kata Kunci: Keterampilan Guru; Media; Kerja Kelompok

\section{PENDAHULUAN}

Upaya guru dalam mengantisipasi terjadinya ketidak tercapaian tujuan dari proses pembelajarannya melalui tindakan inovatif dan kreatif dalam perspektif pencapaian tujuan tersebut. Salah satu langkah antisipatif tersebut adalah guru harus memiliki berbagai keterampilan yang mendukung profesinya sebagai guru. Salah satu keterampilan yang harus dimiliki guru adalah keterampilan dalam menggunakan media pembelajaran.

Keterampilan dalam menggunakan berbagai media pembelajaran mutlak dimiliki oleh setiap guru. Sebagaimana yang dikemukakan Yutmini (Rasto. Net) bahwa, persyaratan kemampuan yang harus dimiliki guru dalam melaksanakan proses belajar mengajar meliputi keterampilan dalam menggunakan media pelajaran. Allen W.H. (dalam Asnawir, 2002: 17) juga menyatakan bahwa "guru hendaknya dapat menggunakan alat bantu yang ekonomis, efisien dan mampu untuk mengimplementasikan dalam proses pembelajaran. Selain itu tidak menolak untuk menggunakan teknologi modern yang relevan dan sesuai dengan tuntutan masyarakat dan perkembangan zaman." Hal serupa dikemukakan oleh Harahap (dalam Rasto. Net) yang menyatakan, kemampuan yang harus dimiliki guru dalam melaksanakan program mengajar adalah mencakup keterampilan dalam 
menggunakan alat-alat bantu pengajaran dengan baik dan benar.

Dengan demikian berdasarkan pengertian tersebut, dapat dipahami bahwa keterampilan guru dalam menggunakan media pembelajaran yang dimaksud dalam penelitian ini adalah keterampilan guru dalam memanfaaan segala media yang dapat dilihat baik yang bergerak maupun yang diam untuk menyampaikan materi pelajaran kepada individunya, sehingga dengan media tersebut dapat membantu guru dalam mengajar dan membantu individu dalam belajar. Sebagaimana yang dikemukakan Syaiful Bahri Djamarah (2006: 140) bahwa keterampilan guru dalam menggunakan media adalah "guru bisa memanipulasi media sebagai sumber belajar dan sebagai penyalur informasi dari bahan yang disampaikan kepada individu dalam proses pembelajaran."

Berdasarkan pendapat di atas dapat dipahami bahwa guru yang terampil dalam menggunakan media pembelajaran haruslah memiliki pengetahuan yang memadai tentang media pembelajaran secara teoritis maupun praktis, mengetahui bagaimana cara menggunakannya dengan baik, dapat menggunakan dan memanfaaannya dalam kegiatan pembelajaran, mampu memilih media yang sesuai, mampu membuat individu termotivasi untuk belajar melalui media yang digunakannya, dan mampu membuat media pembelajaran yang sederhana.

Berdasarkan hasil observasi awal peneliti sebagian besar guru di SDN 011 Tanjung Penyembal Kota Dumai kurang memiliki keterampilan dalam menggunakan media pembelajaran dengan baik, sebagaimana yang dapat dilihat pada tabel berikut ini:

Tabel 1
Keterampilan Guru dalam Menggunakan Media (Kondisi Awal)

\begin{tabular}{|l|c|c|c|c|c|}
\hline \multirow{2}{*}{ Nama Guru } & \multicolumn{5}{|c|}{$\begin{array}{c}\text { Keterampilan Guru dalam } \\
\text { Menggunakan Media }\end{array}$} \\
\cline { 2 - 6 } & 1 & 2 & 3 & 4 & 5 \\
\hline Afrizal, S.Pd & & $\sqrt{ }$ & & & $\sqrt{ }$ \\
\hline Eko Subandi, S.Pd & $\sqrt{ }$ & & $\sqrt{ }$ & $\sqrt{ }$ & \\
\hline $\begin{array}{l}\text { Tito Riswono, } \\
\text { S.Pd }\end{array}$ & & & & & \\
\hline Misriani, S.Pd & $\sqrt{ }$ & & & & \\
\hline Norazila, S.Pd & & & & & \\
\hline Kasri, S.Pd & & $\sqrt{ }$ & & & \\
\hline Ratna Dewi, S.Pd & & & & & $\sqrt{ }$ \\
\hline Ramadhan, S.Pd & $\sqrt{ }$ & & & & \\
\hline Junianto, S.Pd & $\sqrt{ }$ & & & $\sqrt{ }$ & \\
\hline Rinto & & $\sqrt{ }$ & & & \\
\hline Sudaryanti, S.Pd & & & $\sqrt{ }$ & & \\
\hline Suwanto, S.Pd & & $\sqrt{ }$ & & & \\
\hline Rani, S.Pd & $\sqrt{ }$ & & & $\sqrt{ }$ & \\
\hline Jumlah & 5 & 4 & 2 & 3 & 2 \\
\hline Persentase & 38 & 31 & 15 & 23 & \\
\hline Rata-Rata & & & $24,4 \%$ & \\
\hline
\end{tabular}

Sumber: Hasil observasi keterampilan guru dalam menggunakan media pembelajaran di SDN 011 Tanjung Penyembal Kota Dumai (Pra Siklus), 2018

Keterangan:

1. Mengetahui bagaimana cara menggunakan berbagai media dengan baik

2. Mampu memilih media yang sesuai dengan tujuan dan materi pelajaran

3. Mampu memilih media sesuai dengan karakteristik individu

4. Mampu membuat individu termotivasi untuk belajar melalui media yang digunakannya

5. Mampu membuat media pembelajaran yang sederhana

Pada tabel di atas diketahui bahwa dari 13 orang guru di SDN 011 Tanjung Penyembal Kota Dumai yang memiliki keterampilan dalam menggunakan media pembelajaran dengan baik hanya $24,4 \%$ dengan perincian: sebanyak $38 \%$ guru dapat menggunakan dan memanfaaan media 
dalam kegiatan pembelajaran, sebanyak $31 \%$ guru mampu memilih media yang sesuai dengan tujuan dan materi pelajaran, sebanyak 1 Kota $\%$ guru mampu memilih media sesuai dengan karakteristik individu, sebanyak 23\% guru mampu membuat individu termotivasi untuk belajar melalui media yang digunakannya, dan sebanyak $15 \%$ guru mampu membuat media pembelajaran yang sederhana.

Dengan demikian persentase guru di SDN 011 Tanjung Penyembal Kota Dumai yang memiliki keterampilan dalam menggunakan media pembelajaran kecil sekali yaitu hanya $24,4 \%$. Artinya sebanyal $75,6 \%$ guru di SDN 011 Tanjung Penyembal Kota Dumai kurang memiliki keterampilan dalam menggunakan media pembelajaran dengan baik.

Salah satu upaya yang dilakukan pengawas di SDN 011 Tanjung Penyembal Kota Dumai dalam meningkaan keterampilan guru dalam menggunakan media pembelajaran adalah dengan melakukan kegiatan kerja kelompok. Sagala dalam Abimanyu (2009: 7.2) mengatakan bahwa kerja kelompok adalah cara pembelajaran dengan mengkondisikan individu dalam kelas dibagi menjadi beberapa kelompok, yaitu setiap kelompok dipandang sebagai satu kesatuan tersendiri untuk mempelajari materi pelajaran yang telah ditetapkan untuk diselesaikan secara bersamasama. Dengan demikian dapat ditarik sebuah kesimpulan bahwa kerja kelompok adalah suatu format pembelajaran yang menitikberaan pada terjadinya interaksi antara anggota yang satu dengan anggota yang lain untuk menyelesaikan tugas tugas belajar secara bersama.

Berdasarkan beberapa pendapat tersebut dapat disimpulkan bahwa dengan kerja kelompok dapat membantu guru di SDN 011 Tanjung Penyembal Kota Dumai dalam meningkaan keterampilannya dalam menggunakan media pembelajaran. Untuk itu peneliti tertarik melakukan penelitian tindakan sekolah dengan tujuan untuk meningkaan keterampilan guru dalam menggunakan media pembelajaran melalui kerja kelompok dengan lokasi penelitian di SDN 011 Tanjung Penyembal Kota Dumai.

Berdasarkan batasan masalah tersebut maka dirumuskan dalam permasalahan sebagai berikut: "Apakah keterampilan guru dalam menggunakan media pembelajaran dapat meningkat melalui kerja kelompok di SDN 011 Tanjung Penyembal Kota Dumai?"

Hipotesis tindakan yang akan diuji dalam penelitian ini adalah "Keterampilan guru dalam menggunakan media pembelajaran dapat meningkat melalui kerja kelompok di SDN 011 Tanjung Penyembal Kota Dumai."

Sesuai dengan rumusan masalah dan hipotesis tindakan tersebut maka tujuan dalam penelitian ini adalah "untuk mengetahui peningkatan keterampilan guru dalam menggunakan media pembelajaran melalui kerja kelompok di SDN 011 Tanjung Penyembal Kota Dumai."

Adapun kegunaan penelitian ini adalah sebagai berikut:

a. Untuk

keterampilan guru dalam menggunakan media pembelajaran melalui kerja kelompok di SDN 011 Tanjung Penyembal Kota Dumai.

b. Menambah wawasan dan keterampilan pengawas dalam melaksanakan supervisi melalui kerja kelompok untuk meningkaan keterampilan guru dalam menggunakan media 
pembelajaran, khususnya di SDN 011 Tanjung Penyembal Kota Dumai.

c. Memberikan informasi bagi pelaksana dan pengelola pendidikan tentang pentingnya meningkaan keterampilan guru dalam menggunakan media pembelajaran melalui kerja kelompok.

\section{METODOLOGI PENELITIAN}

Jenis penelitian ini adalah Penelitian Tindakan Sekolah, yaitu melakukan tindakan sekolah dalam upaya meningkaan kinerja guru dalam pembelajaran melalui tindakan pelaksanaan kerja kelompok.

Penelitian menggunakan desain Penelitian Tindakan Sekolah model Kurt Lewin. Konsep pokok PTS menurut Kurt Lewin terdiri dari empat komponen, yaitu: perencanaan (planning), tindakan (acting), pengamatan (observating), dan refleksi (reflecting). Hubungan keempat komponen itu dipandang sebagai satu siklus.

\section{Subjek Penelitian}

Subjek penelitian adalah guru di SDN 011 Tanjung Penyembal Kota Dumai tahun pelajaran 2018/2019 yang berjumlah 13 orang.

\section{Teknik Pengumpulan Data}

Digunakan untuk mengetahui peningkatan keterampilan guru dalam menggunakan media pembelajaran. Observasi bertugas untuk melakukan pengamatan dan penilaian melalui pengisian lembar kegiatan pembelajaran guru pada setiap pertemuan.

Catatan Lapangan

Teknik catatan lapangan digunakan untuk mencatat kelemahan, kekurangan, dan hal-hal lainnya yang perlu diperbaiki dan didiskusikan untuk pelaksanaan tindakan pada siklus selanjutnya.

\section{Teknik Analisis Data}

Agar data yang dikumpulkan menjadi bermakna dan dapat digunakan sebagai dasar penentu keberhasilan penelitian, data perlu diolah dan dianalisis. Data-data yang berupa angka (data kuantitatif) diolah untuk mencari rata-rata, data tertinggi, data terendah. Data kualitatif diolah dengan menghitung persentase dari data-data yang sejenis. Setelah itu, hasil pengolahan datanya diuji beda dengan membandingkan kondisi awal, kondisi pada/setelah siklus I dan kondisi pada/setelah siklus II. Dari uji komparasi tadi bisa dilihat perubahan atau peningkatan keterampilan guru dalam menggunakan media pembelajaran.

\section{HASIL PENELITIAN DAN PEMBAHASAN}

Siklus pertama dilaksanakan di bulan November 2018, yaitu pada tanggal 3 - 10 November 2018. Pada tanggal 3 - 4 November 2018, dilakukan pembinaan dan pembimbingan guru secara berkelompok dan simulasi penggunaan media pembelajaran. Pada tanggal Kota - 10 November 2018, pelaksanan penggunaan media pembelajaran di dalam kelas.

Pelaksanaan kerja kelompok pada siklus I dilakukan dengan langkahlangkah sebagai berikut:

1) Guru dikelompokan sebagai 3 kelompok yang masing-masing kelompok terdiri dari 4 anggota dan satu kelompok yang beranggotakan Kota orang.

2) Supervisor meyakinkan guru bahwa melalui bantuan supervisor guru akan dapat mengetahui kelebihan, 
kelemahan dan atau kekurangannya dalam menggunakan media pembelajaran.

3) Supervisor menjelaskan tentang keterampilan guru dalam menggunakan media pembelajaran.

4) Setiap kelompok diberikan tugas untuk berlatih dalam menggunakan media pembelajaran.

5) Setiap kelompok mempresentasikan hasil diskusinya kelompoknya.

6) Supervisor bersama guru membicarakan dan menyepakati pelatihan untuk meningkaan keterampilan menggunakan media pembelajaran selama proses pembelajaran berlangsung dikelas.

7) Setelah ada kesepakatan bersama antara supervisor dengan guru kemudian kedua belah pihak menandatangani kontrak tersebut dan siap untuk melaksanakan kegiatan mengajar yang diamati oleh supervisor.

8) Masing-masing guru mulai melaksanakan kegiatan pembelajaran sesuai dengan keterampilan dalam menggunakan media pembelajaran dan latihan yang diberikan supervisor secara berkelompok di kelas masingmasing.

Kegiatan observasi dilakukan peneliti dan observer dengan dipandu lembar observasi yang sudah dipersiapkan sebelum kegiatan penelitian. Hal-hal yang diobservasi dalam kegiatan penelitian tindakan sekolah ini adalah:
1) Mengobservasi kegiatan supervisor

2) Mengobservasi keterampilan guru dalam menggunakan media pembelajaran

Berdasarkan hasil observasi kegiatan supervisor selama melaksanakan kerja kelompok, adalah: peneliti sudah menerapkan kerja kelompok dengan cukup baik seperti sebelum dilaksanakan supervisi, guru diyakinkan supervisor terlebih dahulu tujuan dilaksanakannya supervisi, sehingga guru bersikap terbuka dan mau bekerja sama dalam meningkaan keterampilan guru menggunakan media pembelajaran. Sebelum dilaksanakan kerja kelompok, supervisor menjelaskan kriteria keterampilan guru dalam menggunakan media pembelajaran, mendemonstrasikan tata cara penggunaan media pembelajaran, memberikan kesempatan kepada guru untuk bertanya dan melakukan simulasi pelaksanaan kriteria tersebut, sehingga guru lebih mudah memahami dalam melaksanakan penggunaan media pembelajaran di kelas. Untuk jelasnya dapat dilihat pada tabel di bawah ini:

Tabel 4

Hasil Observasi Keterampilan Guru dalam Menggunakan Media Pembelajaran Siklus I

\begin{tabular}{|l|c|c|c|c|c|}
\hline \multicolumn{1}{|c|}{ Nama Guru } & \multicolumn{5}{|c|}{$\begin{array}{c}\text { Keterampilan Guru dalam } \\
\text { Menggunakan Media } \\
\text { Pembelajaran }\end{array}$} \\
\cline { 2 - 7 } & 1 & 2 & 3 & 4 & 5 \\
\hline Afrizal, S.Pd & & & $\sqrt{ }$ & & \\
\hline Eko Subandi, S.Pd & $\sqrt{ }$ & $\sqrt{ }$ & & $\sqrt{ }$ & $\sqrt{ }$ \\
\hline Tito Riswono, S.Pd & & $\sqrt{ }$ & $\sqrt{ }$ & & \\
\hline Misriani, S.Pd & $\sqrt{ }$ & $\sqrt{ }$ & & $\sqrt{ }$ & $\sqrt{ }$ \\
\hline Norazila, S.Pd & & & $\sqrt{ }$ & & \\
\hline Kasri, S.Pd & $\sqrt{ }$ & $\sqrt{ }$ & & $\sqrt{ }$ & \\
\hline Ratna Dewi, S.Pd & & $\sqrt{ }$ & & $\sqrt{ }$ & $\sqrt{ }$ \\
\hline Ramadhan, S.Pd & $\sqrt{ }$ & $\sqrt{ }$ & $\sqrt{ }$ & $\sqrt{ }$ & \\
\hline Junianto, S.Pd & $\sqrt{ }$ & & $\sqrt{ }$ & $\sqrt{ }$ & $\sqrt{ }$ \\
\hline Rinto & & $\sqrt{ }$ & & & \\
\hline Sudaryanti, S.Pd & $\sqrt{ }$ & $\sqrt{ }$ & $\sqrt{ }$ & $\sqrt{ }$ & $\sqrt{ }$ \\
\hline
\end{tabular}




\begin{tabular}{|l|c|c|c|c|c|}
\hline Suwanto, S.Pd & & $\sqrt{ }$ & & & \\
\hline Rani, S.Pd & $\sqrt{ }$ & $\sqrt{ }$ & $\sqrt{ }$ & $\sqrt{ }$ & $\sqrt{ }$ \\
\hline Jumlah & 7 & 10 & 7 & 8 & 6 \\
\hline Persentase & $54 \%$ & $\begin{array}{c}77 \\
\%\end{array}$ & $54 \%$ & $\%$ & $46 \%$ \\
\hline Rata-Rata & \multicolumn{7}{|c|}{$58,6 \%$} \\
\hline
\end{tabular}

Sumber: Data olahan penelitian, 2018

Keterangan:

1. Mengetahui bagaimana cara menggunakan berbagai media dengan baik

2. Mampu memilih media yang sesuai dengan tujuan dan materi pelajaran

3. Mampu memilih media sesuai dengan karakteristik individu

4. Mampu membuat individu termotivasi untuk belajar melalui media yang digunakannya

5. Mampu membuat media pembelajaran yang sederhana

Pada tabel di atas diketahui bahwa setelah dilaksanakan kerja kelompok pada 13 orang guru di SDN 011 Tanjung Penyembal Kota Dumai pada siklus I ada peningkatan keterampilan guru dalam menggunakan media pembelajaran, dengan rata-rata Kota8,6\% dengan perincian: sebanyak Kota4\% guru dapat menggunakan dan memanfaaan media dalam kegiatan pembelajaran, sebanyak $77 \%$ guru mampu memilih media yang sesuai dengan tujuan dan materi pelajaran, sebanyak 54\% guru mampu memilih media sesuai dengan karakteristik individu, sebanyak $62 \%$ guru mampu membuat individu termotivasi untuk belajar melalui media yang digunakannya, dan sebanyak $46 \%$ guru mampu membuat media pembelajaran yang sederhana.

Berdasarkan hasil pengamatan terhadap aktivitas supervisor dan keterampilan guru dalam menggunakan media pembelajaran pada siklus I, dapat dinyatakan bahwa pada siklus I pelaksanaan kerja kelompok telah mampu meningkaan keterampilan guru dalam menggunakan media pembelajaran, dimana dari data awal rata-rata keterampilan guru dalam menggunakan media pembelajaran hanya $24,4 \%$ meningkat pada siklus I menjadi $58,6 \%$. Artinya ada peningkatan keterampilan guru dalam menggunakan media pembelajaran sebesar 34,2\%.

Akan tetapi peningkatan keterampilan guru dalam menggunakan media pembelajaran pada siklus I tersebut belum mencapai kriteria keberhasilan penelitian yang telah ditetapkan yaitu $75 \%$, sehingga dapat dikatakan pada siklus I pelaksanaan kerja kelompok belum berhasil meningkaan keterampilan guru dalam menggunakan media pembelajaran dengan optimal.

Untuk perlu dilakukan siklus II dengan memperbaiki tindakan pada pelaksaan kerja kelompok sebagai berikut:

1) Mengubah anggota kelompok kerja guru berdasarkan kesulitan dan kekurangan yang diperoleh supervisor dari hasil pengamatan langsung dalam kegiatan pembelajaran di kelas.

2) Supervisor dan guru mendiskusikan kesulitan dan kekurangan yang telah dilakukannya.

3) Supervisor dan guru mendiskusikan hal-hal yang harus diperbaiki dan dilatihnya.

4) Masing-masing kelompok kerja diberikan latihan dalam menggunakan media pembelajaran sesuai dengan kekurangannya.

5) Guru kembali melatih kemampuannya dalam menggunakan media pembelajaran di kelas. 
Kegiatan observasi dilakukan peneliti dan observer dengan dipandu lembar observasi yang sudah dipersiapkan sebelum kegiatan penelitian. Hal-hal yang diobservasi dalam kegiatan penelitian tindakan sekolah ini adalah:

1) Mengobservasi kegiatan supervisor.

2) Mengobservasi keterampilan guru dalam menggunakan media pembelajaran.

Berdasarkan hasil observasi kegiatan supervisor selama melaksanakan kerja kelompok pada siklus II, adalah: Mengubah anggota kelompok kerja guru berdasarkan kesulitan dan kekurangan yang diperoleh supervisor dari hasil pengamatan langsung dalam kegiatan pembelajaran di kelas. Supervisor dan guru mendiskusikan kesulitan dan kekurangan yang telah dilakukannya. Supervisor dan guru mendiskusikan halhal yang harus diperbaiki dan dilatihnya. Masing-masing kelompok kerja diberikan latihan dalam menggunakan media pembelajaran sesuai dengan kekurangannya. Guru kembali melatih kemampuannya dalam menggunakan media pembelajaran di kelas. Untuk jelasnya dapat dilihat pada tabel di bawah ini:

Adapun hasil pengamatan terhadap keterampilan guru dalam menggunakan media pembelajaran setelah dilakukan perbaikan tindakan dalam melaksanakan kerja kelompok pada siklus II dapat dilihat pada tabel di bawah ini:

Tabel 6

Hasil Observasi Keterampilan Guru dalam Menggunakan

Media Pembelajaran Siklus II

\begin{tabular}{|c|c|c|c|c|c|}
\hline Nama Guru & \multicolumn{5}{|c|}{$\begin{array}{c}\text { Keterampilan Guru dalam } \\
\text { Menggunakan Media } \\
\text { Pembelajaran }\end{array}$} \\
\cline { 2 - 6 } & 1 & 2 & 3 & 4 & 5 \\
\hline
\end{tabular}

\begin{tabular}{|c|c|c|c|c|c|}
\hline Afrizal, S.Pd & & $\sqrt{ }$ & & $\sqrt{ }$ & $\sqrt{ }$ \\
\hline Eko Subandi, S.Pd & $\sqrt{ }$ & $\sqrt{ }$ & $\sqrt{ }$ & $\sqrt{ }$ & $\sqrt{ }$ \\
\hline Tito Riswono, S.Pd & $\sqrt{ }$ & $\sqrt{ }$ & $\sqrt{ }$ & $\sqrt{ }$ & $\sqrt{ }$ \\
\hline Misriani, S.Pd & $\sqrt{ }$ & $\sqrt{ }$ & & $\sqrt{ }$ & $\sqrt{ }$ \\
\hline Norazila, S.Pd & $\sqrt{ }$ & $\sqrt{ }$ & $\sqrt{ }$ & & \\
\hline Kasri, S.Pd & $\sqrt{ }$ & $\sqrt{ }$ & $\sqrt{ }$ & $\sqrt{ }$ & \\
\hline Ratna Dewi, S.Pd & $\sqrt{ }$ & $\sqrt{ }$ & & $\sqrt{ }$ & $\sqrt{ }$ \\
\hline Ramadhan, S.Pd & $\sqrt{ }$ & $\sqrt{ }$ & $\sqrt{ }$ & $\sqrt{ }$ & $\sqrt{ }$ \\
\hline Junianto, S.Pd & $\sqrt{ }$ & $\sqrt{ }$ & $\sqrt{ }$ & $\sqrt{ }$ & $\sqrt{ }$ \\
\hline Rinto & & $\sqrt{ }$ & $\sqrt{ }$ & & $\sqrt{ }$ \\
\hline Sudaryanti, S.Pd & $\sqrt{ }$ & $\sqrt{ }$ & $\sqrt{ }$ & $\sqrt{ }$ & \\
\hline Suwanto, S.Pd & $\sqrt{ }$ & $\sqrt{ }$ & $\sqrt{ }$ & $\sqrt{ }$ & $\sqrt{ }$ \\
\hline Rani, S.Pd & $\sqrt{ }$ & $\sqrt{ }$ & $\sqrt{ }$ & $\sqrt{ }$ & $\sqrt{ }$ \\
\hline Jumlah & 11 & 13 & 10 & 11 & 10 \\
\hline Persentase & $85 \%$ & $\begin{array}{c}100 \\
\%\end{array}$ & $\begin{array}{l}77 \\
\%\end{array}$ & $\begin{array}{l}85 \\
\%\end{array}$ & $\begin{array}{l}77 \\
\%\end{array}$ \\
\hline Rata-Rata & \multicolumn{5}{|c|}{$84,8 \%$} \\
\hline
\end{tabular}

Sumber: Data olahan penelitian, 2018

Keterangan:

1. Mengetahui bagaimana cara menggunakan berbagai media dengan baik

2. Mampu memilih media yang sesuai dengan tujuan dan materi pelajaran

3. Mampu memilih media sesuai dengan karakteristik individu

4. Mampu membuat individu termotivasi untuk belajar melalui media yang digunakannya

5. Mampu membuat media pembelajaran yang sederhana

Pada tabel di atas diketahui bahwa setelah dilakukan perbaikan tindakan dalam melaksanakan kerja kelompok pada 13 orang guru di SDN 011 Tanjung Penyembal Kota Dumai pada siklus II ada peningkatan keterampilan guru dalam menggunakan media pembelajaran, dengan rata-rata $84,8 \%$, dengan perincian: sebanyak $85 \%$ guru dapat menggunakan dan memanfaaan media dalam kegiatan pembelajaran, sebanyak $100 \%$ guru mampu memilih media yang sesuai dengan tujuan dan materi pelajaran, sebanyak $77 \%$ guru mampu memilih media sesuai dengan karakteristik individu, sebanyak $85 \%$ 
guru mampu membuat individu termotivasi untuk belajar melalui media yang digunakannya, dan sebanyak $77 \%$ guru mampu membuat media pembelajaran yang sederhana.

Berdasarkan hasil pengamatan terhadap aktivitas supervisor dan keterampilan guru dalam menggunakan media pembelajaran pada siklus II, dapat dinyatakan bahwa pada siklus II pelaksanaan kerja kelompok berhasil meningkaan keterampilan guru dalam menggunakan media pembelajaran di SDN 011 Tanjung Penyembal Kota Dumai sesuai dengan indikator keberhasilan penelitian yang diinginkan yaitu 7 Kota\% keterampilan guru dalam menggunakan media pembelajaran meningkat.

Pada siklus II, terjadi peningkatan keterampilan guru dalam menggunakan media pembelajaran dengan rata-rata $84,8 \%$. Berdasarkan hasil penelitian tindakan kelas pada siklus II tersebut maka tidak perlu dilakukan tindakan pada siklus selanjutnya dan penelitian ini berakhir dan telah berhasil mencapai tujuan penelitian yaitu peningkatan keterampilan guru dalam menggunakan media pembelajaran melalui kerja kelompok di SDN 011 Tanjung Penyembal Kota Dumai.

Hasil penelitian ini sesuai dengan pendapat yang dikemukakan Sagala tujuan kerja kelompok adalah 1) Memecahkan masalah pembelajaran melalui proses kelompok, 2) Mengembangkan kemampuan bekerjasama di dalam kelompok.

Alasan menggunakan kerja kelompok adalah sebagai berikut: 1) Kerja kelompok dapat mengembangkan perilaku gotong royong dan demokratis. 2) Kerja kelompok dapat memacu individu aktif belajar. 3) Kerja kelompok tidak membosankan individu melakukan kegiatan belajar diluar kelas bahkan diluar sekolah yang bervariasi, seperti observasi, wawancara, cari buku di perpustakaan umum, dan sebagainya.

Adapun kekuatan/kelebihan dari kerja kelompok adalah sebagai berikut: 1) Membiasakan individu bekerja sama, bermusyawarah dan bertanggung jawab. 2) Menimbulkan kompetisi yang sehat antarkelompok, sehingga akan membangkian kemauan belajar yang sungguh-sungguh. Guru dipermudah tugasnya karena tugas kerja kelompok cukup disampaikan kepada para ketua kelompok. 3) Ketua kelompok dilatih menjadi pemimpin yang bertanggung jawab, dan anggotanya dibiasakan patuh pada aturan yang ada.

Agar kerja kelompok semakin efektif dan efisien dalam meningkaan keterampilan guru dalam menggunakan media pembelajaran, maka dalam pelaksanaannya hendaknya memperhatikan beberapa prinsip sebagai berikut:

1. Pendekatan yang dilakukan dalam proses kerja kelompok adalah pendekatan profesional dan humanis

2. Instrumen yang disusun atas dasar kesepakatan antara supervisor dengan guru

3. Feedback yang diberikan harus secepat mungkin dan secara obyektif

4. Bimbingan supervisor kepada guru bersifat bantuan, bukan perintah atau instruksi

5. Jenis keterampilan yang akan disupervisi diusulkan oleh guru, disepakati melalui pengkajian bersama antara guru dan supervisor

6. Sasaran supervisi hanya pada beberapa keterampilan tertentu

7. Dalam diskusi atau pertemuan balikan, guru diminta terlebih dahulu untuk mengevaluasi penampilannya 
8. Supervisor lebih banyak bertanya dan mendengarkan dari pada memerintah atau mengarahkan

9. Supervisi berlangsung dalam suasana intim dan terbuka

\section{SIMPULAN}

Berdasarkan hasil penyajian data dan pembahasan, maka dapat diambil kesimpulan bahwa pelaksanaan kerja kelompok dapat meningkaan keterampilan guru dalam menggunakan media pembelajaran di SDN 011 Tanjung Penyembal Kota Dumai.

Kesimpulan penelitian tersebut berdasarkan temuan penelitian bahwa pada pra siklus rata-rata keterampilan guru dalam menggunakan media pembelajaran hanya 24,4\%. Setelah dilaksanakan kerja kelompok pada siklus I, keterampilan guru dalam menggunakan media pembelajaran meningkat sebanyak 58,6\%. Setelah dilakukan perbaikan tindakan dalam melaksanakan kerja kelompok pada siklus II, keterampilan guru dalam menggunakan media pembelajaran semakin meningkat sebanyak $84,8 \%$. Dengan demikian hipotesis tindakan dalam penelitian ini diterima yaitu "Ada peningkatan keterampilan guru dalam menggunakan media pembelajaran melalui kerja kelompok di SDN 011 Tanjung Penyembal Kota Dumai."

\section{UCAPAN TERIMA KASIH}

Pada akhirnya, penulis menyadari bahwaartikel ini tidak akan selesai tanpa dukungan dari rekanrekan Dinas Pendidikan dan Kebudayaan Kota Dumai atas segala bantuan dan dukungan yang telah diberikan.

\section{DAFTAR PUSTAKA}

Djamarah, Syaiful Bahri dan Zain, Aswan. 2006. Strategi Belajar Mengajar, Jakarta: Rineka Cipta.

Djaali, 2007. Psikologi Pendidikan. Jakarta: Bumi Aksara

Hamalik, Oemar. 2005. Kurikulum dan Pembelajaran. Jakarta: Bumi Aksara 1990. Evaluasi Kurikulum. Bandung: Remaja Rosdakarya.

Ibrahim, R. dan Sukmadinata, Nana Syaodih. 1996. Perencanaan Pengajaran, Jakarta: Rineka Cipta.

Idris, Zahara dan Jamal, Lisma. 1992. Pengantar Pendidikan , Jakarta: Grasindo.

Nurdin, Syafruddin dan Usman, Basyiruddin. 2003. Guru Profesional dan Implementasi Kurikulum, Jakarta: Ciputat Press.

Rohani, Ahmad. 1997. Media Instruksional Edukatif, Jakarta: Rineka Cipta.

Sagala, Syaiful. 2007. Konsep dan Makna Pembelajaran. Bandung: Alfabeta.

Sanjaya, Wina. 2008. Strategi Pembelajaran Berorientasi Standar Proses Pendidikan. Jakarta: Kencana.

Sardiman, 2007. Interaksi dan Motivasi Belajar Mengajar. Jakarta: Raja Grafindo Persada.

Syah, Muhibbin, 2010. Psikologi Belajar. Jakarta: Rajawali Pers. 
1997. Psikologi

Pendidikan dengan Pendekatan

Baru. Bandung: Remaja Rosdakarya

Sugiyono. 2008. Metode Penelitian Pendidikan Pendekatan

Kuantitaif, Kualitatif dan $R \& D$, Bandung: Alfabeta.
Uno, Hamzah B. 2008. Profesi Kependidikan, Jakarta: Bumi Aksara

Usman, Moh. Uzer. 2001. Menjadi Guru Profesional, Bandung: Remaja Rosdakarya. 